\title{
Capital/Labour Separation in french agriculture: The End of Family Farming?
}

\begin{abstract}
While, historically, the family nature of farms has been depending mainly on the fact that capital and labour are in the same hands, developments in the French countryside lead to questioning this "historical" model, in that certain forms found today in production processes clearly seem to move away from it. This article, based on the statistical data available to date, identifies elements indicating major changes and introduces a few concrete cases, found here and there, illustrating major qualitative changes. The analysis then bears on the issue of the transfer of the most capitalised farms, and on the "flexible farming" model proposed by CERFrance. The capital/labour separation process at work and its possible outcome are brought to light, particularly as regards value added distribution.
\end{abstract}

Keywords: Agriculture, France, Capital-Labour Separation, Firm, Comparative Agriculture

\section{Introduction: Family Farming and the Organic Capital/Labour Relation}

We know that the French post-war agricultural model and the development process characterising the second half of the $20^{\text {th }}$ century were founded on family farming, involving a couple where both contributed their labour. Family farming acted as the main model enabling major yield increases - and in particular, increased labour productivity - in the French agricultural sector after the war. Nevertheless, while the contemporary agricultural revolution did deliver productivity gains for family farms, the unprecedented increase in the capitalisation of these farms did not transform them into "capitalist" farms.

On the occasion of the International Year of Family Farming (AIAF), many countries reexamined what 'family farming' stood for. While in this article we do not intend to review these discussions in detail we would like to recall that, on the whole, there was worldwide consensus concerning abandoning any size criterion and instead using criteria characterising the farm operation, focusing on the family unit, after Tchayanov (1929). Neither are the level of technical equipment (and therefore the surface area being farmed) nor the nature of trading (resorting to the market to acquire means of production, auto-consumption of production versus marketing of output) appropriate defining criteria (e.g. Bélières and co, 2013; Sourisseau ed., 2014; FAO, 2014).

From our perspective, the "family" nature of the production unit, in France and elsewhere, depends first of all on the fact that the major share of the work required is carried out by the actual farmer and, if need be, his/her spouse, children or even members of the older generation. Furthermore, it depends on the fact that the two production factors of labour and capital are in the same hands ${ }^{1}$. This is what makes family farming as a production unit very different from a capitalist-type undertaking where the labour force is remunerated with a

1 Where the farmer may or may not own the land. 
salary, while the owner of the capital, the businessman, is remunerated with profit as a return on invesment. With family farming, the economic result of the production process is translated into agricultural income on which the farmer and farm family can live and, where possible, increase their productive capital, a notion far removed from that of capitalist-type profit $^{2}$.

As such, our conception of "family" farming differs significantly from those put forward in other circles. In a more sociological conception of family farming for example, the involvement of the entire family (i.e. several generations) or a few members only, is what makes "family farming". In this context as soon as the labour force is reduced to one labourer (i.e. the farmer himself), while the spouse works outside the farm, the family nature of the production unit is questioned. In other characterisations it is the fact that the family holds the land as well as the capital involved in the productive process, and the fact that land and capital transmission is maintained "within the family framework", that are seen to justify the family nature of the farm, whereas the major part of the labour is no longer contributed by the family.

By sticking specifically to this capital/labour relation that, according to our definition, underlies the family or non-family nature of agriculture, we find that developments in the French countryside led us to question the "historical" model of family farming, insofar as certain forms found today in production processes clearly seem to move away from it. In this article, we will first try to identify, based on the statistical data available to date, elements that potentially indicate major change. Drawing from a number of case studies involving fieldwork undertaken in the French countryside, we will pinpoint certain qualitative developments that, despite being illustrative and barely visible in the statistics, appear particularly meaningful, in this context. The analysis will focus upon the issue of the transfer of the most capitalised farms, and on exploring the implications of the "flexible farming" management model as proposed by CER-France. We conclude our analysis by considering the capital/labour separation process at work in the French countryside, and its possible outcomes, particularly as regards value-added distribution.

\section{New Discreet Forms of Capital/Labour Relations}

Noting the expansion of the largest and best-equipped farms and the continual decrease in farm numbers across France in recent decades (provide some references to authors who have described these processes, here) is not enough to infer that family farming might be disappearing or moving towards a 'capitalist' farming model. In fact, many recent technological developments (e.g. high capacity milking equipment, increases in plot width and GPS-guided engines, GMO kits and simplified cash crop management sequences among others), show that pursuing productivity gains is still possible within the framework of the same family "model"3.

\section{Precursory Signs from Statistics}

\footnotetext{
2 Rather than a clear-cut definition, this is more about a continuum of production forms between the two extremes of family- and capitalist-type farming, so that it is often essential to identify (and as such characterise) the "employers-type" undertakings in which the family labour force is mobilised, jointly with the agricultural labour force hired on a seasonal or permanent basis (Dufumier and Bergeret, 2002).

3 See also the American case in which, contrary to popular belief, the majority of production units remained family-based with cash crops in particular, which does not seem to have prevented significant productivity gains (Devienne S. et al., 2005, Devienne, 2014).
} 
Although available farm statistics (RGA, RICA) do not reflect any significant move towards capitalist agriculture, there have been some signs offering a glimpse of the nature of ongoing developments. These are summarised below.

\section{Appearance of Very Large Farms}

By adopting the Standard Gross Production (SGP) criterion in measuring the "economic" size of farms, two new farm categories (in addition to the small, average and large ones adopted by the Statistics and Foresight Department of the French Ministry of Agriculture) were revealed: the category of very large farms with an SGP of more than $€ 250000$, and that of giant farms with an SGP of more than $€ 1$ million (Olivier-Salagnac and Legagneux, 2012). According to these authors, in 2010 these two farm categories which are still in a minority (10.5\% of the total), used $23 \%$ of the total Usable Agricultural Area (UAA) and produced $53 \%$ of the SGP (idem p. 88$)^{4}$.

Where cash cropping is concerned, Philippe Perrier-Cornet estimated that, in 2007, there were around one thousand very large farms which, in the French context, cover between 1000-3000 ha (Carlier and Perrier-Cornet, 2007). Many of them are contract farming businesses carrying out all the cultivations (infra) on behalf of several "client" farms. Today, these businesses have greater influence on farm land, even if this phenomenon remains hidden in the agricultural statistics, where each "client" farm maintains its farmer status. Nonetheless, it is possible to detect when these businesses grow in size from when they show an increase in the number of salaried employees. Indeed, in parallel to the fact that service provision is on the increase, the number of salaried employees hired by farming businesses, farm machinery cooperatives and employer groups is also on the increase (infra).

Where animal production is concerned, the appearance of very large structures is also manifest. In 2010, two thousand of the largest dairy farms in France produced one million litres of milk each, on average (Institut de l'élevage, 2013), while some of the businesses specialised in beef farming have also reached very large sizes, calling to mind the fattening units of the Po Valley 5 .

\section{The Development of Business Structures}

We know that the number of farms adopting various more 'corporate' business structures (e.g. GAEC? EARL?) has greatly increased in the last few years. In 2010 in Metropolitan France, they represented $30.6 \%$ of farms and covered $57.1 \%$ of the UAA (MAAF, Agreste 2010). Some of these developments do not question the fact that these are family farms, i.e. where both capital and labour are in the same hands. The case of Collective Farming Groupings (which ones - GAEC?) illustrates this situation, with many of these associating fathers and sons, mothers and sons or, still, brothers. The same applies to farms adopting specific legal structures (EARLs?) which have as their main objective tax optimisation ${ }^{6}$.

\footnotetext{
$4 \quad$ Because this farm type is highly represented in the quality wine industry and intensive indoor production, it uses relatively little surface area (idem).

For example, the Berneuil Estate (Haute Vienne) which, in 2013, "conditioned" around 6000 heads of lean cattle for its parent company settled in the Po Valley (interview conducted in Berneuil with Olivier Ducourtieux, May 2013).

$6 \quad$ Within the framework of this article, we will not tackle the scenario where these structures are created partly to favour farm expansion (when an associate leaves the company) and as such bypass the obstacles that are still sometimes activated by measures for the control of facilities.
} 
Moreover, these business structures are increasingly active on the land market and have been buying the largest and most expensive estates... In 2013, agricultural legal entities (agricultural land groupings, agricultural property investment companies and agricultural companies) acquired $9.2 \%$ of estates on sale, $12.4 \%$ of their surface area and $21.4 \%$ of their value (FNSafer, 2014). In addition, the national land agency FNSafer found that Investment Funds have announced their intention to enter the agricultural land market in France, which seems to be an entirely new phenomenon...

\section{Increase in Salaried Employment}

Finally, after half a century of constant reduction in the number of salaried employees in the French agricultural sector (in absolute and relative terms), a reduction that went hand in hand with productivity gains and, at the same time, established the dominance(?) of the family farm model, this trend became reversed during the past 20 years or so. It had been declining up to the 1988 census, reaching its lowest level (10\% of permanent non-family AWUs), and began increasing again, reaching 16\% in Metropolitan France during the 2000 Agricultural Census, then $19.4 \%$ in that of 2010 (RGA, 2010). It reached $30 \%$ in the large farm category, there accounting for $82.3 \%$ of permanent salaried AWUs (excluding seasonal labour, occasional labour, farming businesses and farm machinery co-operatives) (Buisson et al., 2014). Moreover, in parallel with the increase in service provision, the number of salaried employees hired by farming businesses, farm machinery co-operatives and employer groups has also been increasing.

By including the seasonal or occasional labour force and all work carried out by the personnel of farming businesses or farm machinery co-operatives (excluding replacements), the number of salaried non-family AWUs compared to the total AWUs in Metropolitan France, went from $25 \%$ in 2000 to over $29 \%$ in $2010^{7}$. Where hiring illegal immigrants is also a common phenomenon in some sectors, the "invisible" nature of this phenomenon is being reinforced (Darpeix, 2013) and it is therefore likely that this figure is in actual fact an underestimate.

\section{Concrete Cases in the French Countryside}

Forms of supply chain integration controlled by the food industry, in animal production in particular, have been known for a long time. In the case of supply contracts (indoor pig or poultry production), all the farmer does is to execute specific requirements; the decisionmaking is already far removed from the producer and includes a production and marketing strategy going way beyond the frame of the production unit. However, the onus of investing in and implementing the production process - or at least part of it - (as well as the inherent risks) rests with the farmer.

Other forms of production have also emerged recently, sometimes less visibly than the previous ones, increasingly bringing farmers to move away from family agriculture. While in

7 In absolute terms, the volume of salaried employment continues to decrease as productivity increases, although much more slowly than the decrease in family labour (Buisson et al., 2014). Only the number of salaried employees in farming businesses and farm machinery co-operatives, is growing in absolute terms. "Complex collectives" are also frequently being set up, bringing together labourers of various status: associate farmers, less qualified and remunerated workers, full-time or part-time salaried employees, workers recruited within the framework of an employer group, etc. 
the statistics some of these transformations are invisible, others could already be noted in the French countryside in the 1990s, as pointed out in Etudes Foncières (2008).

Concerning crop production, for example, we can cite the case of melon-producing companies (in the Poitou region for example), or potato-producing companies (Flanders or pays de Caux) that enter into contracts with farmers who agree to let them use certain plots of land, for a season. Contracts are annual, which allows the company to disregard cropping plan constraints. Even if the farmer sometimes contributes part of the labour required in accordance with specific requirements, he is no longer the owner of the actual crop, and the true production process is entirely managed and controlled by the company ${ }^{8}$.

In cash crop regions, it was not rare, as early as the 1980 s, to see a farmer in trouble - or at the end of his career, without successor and reluctant to renew his equipment - entrusting his farm to a farming business. By undertaking all the cultural operations, the farming business ended up managing the farm de facto. Sometimes, in order to rationalise labour time and machinery usage, the farming business established only one crop on the "client" farm, and would already plan rotations along with other farms where the same "full service" was offered. The ultimate outcome of this process would be when the client rids himself completely of farming equipment, and obtains all farm inputs from the service provider. A tenant farmer's remuneration would then be calculated in such a way that the income received would barely cover the farm rent and social security contributions ${ }^{9}$. Insofar as any form of subletting was prohibited within the framework of the statutes on tenant farming and collective crop rotations (that were not yet legally recognised), this type of arrangement was not formalised by contract, and remained informal. Sometimes also, land owners took 'in hand' land that was free once its lease expired, but had the farming carried out ipso facto by a farming business offering full agricultural services. In other cases, retiring farmers whose sons had their own careers but who decided to take over the farm (instead of leasing the land as tenant farming), had it farmed "from A to Z" by a farming business ${ }^{10}$.

By legalising "collective rotations" (by possibly creating a joint-venture company for example), the Blueprint Law of 2006 facilitated the development of this type of operation, while relaxing the conditions underlying the control of facilities, which in the past required clever manœuvering to avoid. This law also extended the possible field of operations of farm machinery co-operatives. Today, with the emergence of farmer projects mutualising part of their activities way beyond their equipment, the FnCUMA clearly intends to capitalise on this trend by promoting types of "agricultural production co-operatives"11, which could develop into business structures where each farmer could hold shares, with no obligation to lend a hand.

\footnotetext{
8 In the case of contracts entered into for the production of melons for example, the farmer carries out the cultivation-related work and all maintenance works "compatible with his equipment", gives the company ownership of the crop and is remunerated with one-fifth of the value of the standing crop (Syndicat des Producteurs de Melon du Haut-Poitou, personal communication, 2008). See also on this theme Pluvinage 2011.

9 .J. Damien N. de Surgy, CER (personal communication 2003).

10 As already seen in Charente for example (interview conducted with S. Devienne in March 2011). Invoicing was based on a package that included, in addition to undertaking the complete crop management sequence, putting together the Common Agricultural Policy dossier, the crop dusting plans, the phytosanitary logbook and insurance certificates, as well as delivering the harvest to the co-operative. The client kept his farmer status and therefore the single payment scheme, ownership of the harvest and the risk inherent in marketing it. See also Séronie (2014) on the subject.
}

11 See for example the FnCUMA Congress held on 28-30 May 2013. 
Beyond the productivity gains allowed by these new forms of production management (i.e. farming businesses, contract farming and farm machinery co-operatives), which can now deal with the cultivation of several thousands of hectares, we find new social relations in which employees take on more importance. For instance, truck drivers in these facilities decreasingly take part in the management of the company, but also fail to see the point of the global vision of the production and marketing process. Technical, organisational and financial management is from now on the prerogative of those who own the capital and the land, types of shareholders whose shares are the surface area brought in by each. Although these shareholders are still farmers, particularly in the eyes of the administration, and sign their own Common Agricultural Policy dossier, they might spend very little time on their tractors ${ }^{12}$.

Where animal production is concerned, as well as the intensive indoor systems mentioned previously, the development of new forms of agriculture progressively moving away from the "family model", has also been virtually invisible, far from the media hype provoked by the "1000-cow factory" project. Ensuring the compliance with Nitrates Directive of livestock buildings and speeding-up restructuring provoked within the dairy industry as a result, are a good example. Indeed, by compelling dairy farmers to carry out major works to ensure compliance, this obligation significantly increased the number of difficulties encountered by small farms, especially since the subsidies supposed to help cattle farmers ensuring their compliance targeted larger farms. In order to avoid the "early" cessation of activities, some accepted partnership proposals made by their neighbours who were better equipped, were able to ensure their own compliance and benefitted from significant public funds. As second-class partners however, these smaller farms were often given the least rewarding tasks and endure an unequal social relationship ${ }^{13}$.

Diverse as they are, it seems to us that the new institutional forms of production management that have emerged in France over the past twenty years or so, i.e. service supply companies, complete farm machinery co-operatives, contract farming, dairy companies, complex combinations of different business structures (e.g. GFA, EARL and SCEA among others), as well as agricultural production companies, some of which have been facilitated by the Agricultural Blueprint Law of 2006, can be analysed from the viewpoint of their common character: an increasingly marked distance between those who provide the capital on the one hand, and those who supply the labour on the other. Indeed, although they are highly diverse and without any direct links between one another, the new forms of social relationships emerging here and there are clearly going in the same direction, that of the progressive weakening of the capital/labour relationship that was behind the family farming model (Cochet, 2008).

\section{Business Structures: from Inheritance Transmission within the Family Framework to Capital/Labour Separation}

While the development of business structures sometimes concerns mere tax optimisation, without fundamentally questioning the family nature of the farm (supra), it also aims at bringing a - temporary - solution to the succession issue, by simplifying takeover. By having other family members dealing with part of the farmland, GFAs, for example, make it possible for the sibling taking over the farm to offload part of the farmland onto his/her brothers and

\footnotetext{
12 See for example the case of the SEP Céres (Champagne berrichonne) presented at the SAF.

13 Interviews conducted in March 2007 with Sophie Devienne, during a field trip. This type of association was legalised in the form of a non-trading dairy company through the Blueprint Law of 2006.
} 
sisters, even if it means paying rent to the GFAs. The creation of business structures, by allowing the distribution of working capital among severalpeople, instead of the sole farmer, addresses the same concern. But this can only be a provisional solution, since sooner or later shareholders will require what is due to them as family relations become looser (siblings, then nephews and nieces among others).

In the end, the issue concerning the control of shares will be raised. As such, who will, in the long run, control the shares of the new business? How long will the farmer maintain actual control over the productive process? Is there a risk that many of these shares end up in the hands of investors in search of high rates of return on investments ${ }^{14}$ ?

Rather than a temporary stop-gap solution, these new legal arrangements are often conceived as support for new forms of production characterised by an increasingly clear separation between those who supply farmland and capital on the one hand, and those who supply the labour on the other. This case scenario represents the ideal type of association-based family agriculture proposed by Hervieu and Purseigle (2009): "The only thing that's "family-based" in these associations, is the management of the estate which is meant to ensure that all associates originating from the same family receive an income" (p. 189). Nguyen and Purseigle give an example of this in the Camargue region. Within the framework of this "family capitalism", capital and farmland remain in the hands of one family (via one or several SCEA- and GFA-type structures), while only one family representative actually works on the farm as manager, with a status of salaried employee of the SCEA of which he is shareholder and production director. The other family members, as shareholders (in the agricultural companies and GFAs), do not work on the farm and have the status of nonoperating associates. The main part of the work is then carried out by salaried employees who are external to the family collective (Nguyen and Purseigle, 2012). Although this farming model is still defined as family farming by these authors, due to the fact that the capital remains in the hands of the family (which actually also happens in many industrial companies), it is clear that the capital/labour separation is at an advanced stage and that active farming, as far as we are concerned, no longer qualifies as family farming.

The Blueprint Law of 2006, with a view to facilitating transfer, aimed explicitly at promoting the potential "delivery of the production factors" by external capital: introduction of an agricultural business based on the commercial business model, lease transferable by the farmer to someone outside the family framework, suppression of the need for a family link between the associates of an EARL, etc. (Gault et al., 2013). Although the supply of production factors by capital external to the family is still fairly rare in the French context, where the incentives in the Blueprint Law of 2006 proved to be insufficient (Gault et al., 2013), it is likely that these new institutional forms will assume more importance in the future, as farm transfer is made increasingly difficult, due to the extension and growth of capital held solely by the farmer. Unless one splits up the farm into several smaller farms, which leads to a change in paradigm as regards agricultural development, one needs to seek the required capital outside the farm, firstly within the close family circle, then by turning to

14 The FNsafer highlights in this regard the lack of clarity of the market of real estate company shares that, as a result, remains untouched by any form of control or registration. The inefficiency of the regulation tools when "monopolizing" is taking place under the cover of associations, then becomes obvious (Gault et al., 2013). However, the French Law on the Future of Agriculture, Food and Forestry, voted in 2014, opens up the way for compulsory information to be supplied by the SAFERs as regards the transfer of agricultural company shares. 
external capital providers, thus ensuring the separation of capital and labour. In the end, will the farmer become a business director who is accountable to a board of directors which is from then on representing the shareholders of a capitalist firm?

\section{Flexible Farms and Flexibility of Production Factors}

By facilitating these developments, particularly by legalising certain practices in force for many years, the Agricultural Blueprint Law of 2006 proposed a way out of the exclusive family farming model, which is perceived as a real constraint by the most influential lobby/group within the agricultural profession. Elements of this law were in fact partly inspired by the 'business intelligence cell' of the French Rural Economic Centres' network (Cochet, 2008). Indeed, this cell had already initiated a discussion on the future of the farm concept (CER, 2005), and formalised a few years later the nnovative concept of "flexible farming" (CER, 2007). According to the authors of this document, the ideal future farm was to result from the joint implementation of three distinct patrimonial, entrepreneurial and technical projects that, if necessary, could be carried out by different persons or institutions:

- Firstly, a patrimonial project carried out by the owner of the farmland. While investing in farmland had generally become financially inviable since the law of 1946, the "transferable lease" introduced by the Blueprint Law of 2005 could give rise to a derestriction of $50 \%$, and make land investment once more financially attractive.

- Then, the "agripreneur" or "entrepreneur of the living", who "must be able to capitalise the growth of his activity with an agricultural business the value of which includes the clientele, multifunctionality, subcontracting and the right to produce (...) as well as farm leases" (CER, 2007, op. cit., p. 2).

- Finally, the "entrepreneur of farm work": whether as "private or co-operative (farm machinery co-operatives), develops a project for the supply of services to agripreneurs with whom (s)he enters into contracts" and "supplies equipment and labour. These services range from one-off interventions to third party involvement" (idem, p. 21).

For the "agripreneur" as imagined by the CER-France network, the idea is to make agricultural business profitable: "where he must frequently adapt (to the market), (the agripreneur) will seek to make most of his costs variable". "The idea is to formalise the maximisation of supply of resources by contract...: transferable lease as far as the farmland is concerned, fixed-term service contracts as far as the equipment and labour are concerned" (idem, p. 18-19). For the CER-France network, recognising the separate identity of these patrimonial, entrepreneurial and technical projects would make it possible to gain "flexibility" and, as such, "to free oneself from the unique family model: family-capital-business". This neo-liberal project, which has underpinned the future duality of French agriculture, clearly indicated a desire to produce for "globalised" markets, with the objective of becoming competitive, independent of public aid. These promoters saw in this the spearhead of future productivity growth in the agricultural sector (Cochet, 2008). "Producing tomorrow with farmers, salaried employees, owners and shareholders", that is what the road map should be like for the main promoter of this model, i.e. "wonderful paths towards a conquering agriculture" (Séronie, 2014). 
Although this new institutional model of agricultural production management is still fairly remote - and will be so for a long time - from the everyday life of French farmers, its theoretical expression by the CER-France network is significant. It illustrates the very real progressive capital/labour separation trend, as illustrated previously (supra), and at the same time the economic model which has been more or less explicitly promoted by some in the agricultural profession.

Moreover, it is reminiscent of other, more established, institutional forms of agricultural production which are already widespread in other regions of the world. This is the case, for example, of the pool de siembra, described by many authors in connection with South America (for example: Posada and Martínez de Ibarreta, 1998; Grosso, 2010; Albaladejo et al., 2012; Guibert, 2013) This model shows many comparable points except that, unlike the "flexible farming" model devised by the accountants of CER-France, it is already experiencing rapid development in South America. It relies on the following principle: different actors, each contributing a portion of the required production factors, come together during an agricultural cycle to implement a simplified technical process, based on one or two short cycle crops, i.e. a transgenic pack made up of genetically modified seeds, glyphosate and direct seeding. The land is rented out by the collective constituted in this manner to former (often family-type) farmers. Investments in fixed assets are then limited to a maximum and everything relies on the supply of services and temporary or even daily labour. The production process in this case results from the combination of capital of diverse origins, brought together during a crop year and sometimes highly remunerated, thereby guaranteeing that this new institutional form will attract new capital. Beyond the great diversity of possible arrangements between actors, we suggest that the pool de siembra constitutes a perfect form of "hyper-flexible" farming, going way beyond the French "flexible farming" project dreamed of by the economists of CER-France.

In order to emerge, the "flexible" farming model would first need increased "administrative flexibility", making it possible in particular to have short-term agreements, as is the case with pools de siembra, instead of relying on the current legal framework which is deemed too rigid $^{15}$. Beyond greater administrative flexibility, that of production factors is also needed: "formalising by contract as many resources as possible to make most costs variable" (supra), labour in particular.

\section{Conclusion: Capital/Labour Separation, Flexibility and Consequences for Value Distribution}

We know that the conditions of access to production factors, widely determined by farmers' social relations, influence value-added distribution (rent, remuneration of external labour, interests on borrowed capital as well as taxes on farmland and farm income). By revealing the social conditions of access to productive resources and labour, value added distribution models highlight the respective "remuneration" of the different production factors, and value added distribution between capital and labour in particular. In family farming, it is the farm income which represents the share of value added (potentially increased by the subsidies received [in the European case]) captured by the farmer and enabling him/her to support the family and, if possible, to invest in the business. This is the criterion that will best indicate the future of the farm

15 See La Lettre veille économique du CER-France, $\mathrm{N}^{\circ}$ 16, June 2009, and the legal proposals compiled by the same team in Les voies juridiques vers l'entreprise agricole flexible (2014). 
and its capacity to develop. In family farming, the largest share of value added produced, is generally allocated to remuneration of the family workforce, in the form of income, except in situations where land access conditions impose a heavy ground rent or where access to capital, via all sorts of contractual arrangements, drastically reduces the share of value added coming to the farmer (Cochet, 2015) ${ }^{16}$.

As soon as an increasingly significant share of the work is carried out by salaried employees, seasonal workers, daily workers or pieceworkers; as soon as part of the capital involved is no longer under the farmer's control, and therefore as soon as an increasingly clear separation is progressively taking place between farm workers on the one hand and capital suppliers on the other, the value added distribution conditions evolve accordingly. Indeed, unlike a family farm for which the separate remuneration of the production factors does not make much sense, an external capital supplier - even if he is related to the farmer - will sooner or later demand that his investment be remunerated at the average interest rate obtainable in other economic sectors, or even higher than that, in the case of shareholders. Such developments underlie new value added distribution patterns between capital and labour, with the capital remuneration share increasing, to the detriment of that dedicated to labour remuneration, a development which is already happening in many regions of the world. The more company size increases, and the more the share of salaried work increases to the point where, in the end, it constitutes the entire work supplied, the more the share of value added dedicated to the remuneration of labour and creation of income decreases (Cochet and Merlet, 2011).

We also find that this distribution, which is increasingly unfavourable to labour, is not only due to an increase in the capital mobilised in the productive process and an increase in labour productivity, but also to a process of disconnection between salary and productivity, and to the replacement of full time posts with seasonal or even daily employment or piecework ${ }^{17}$. Consequently, investments and increases in labour productivity no longer aim at increasing (or maintaining) labour remuneration (as is the case with family farming). They aims particularly to increase the remuneration of capital investors, a necessary condition to ensure that the agricultural sector attracts external capital from outside the sector (Cochet, 2015).

In the light of ongoing developments in many regions of the world, the current transformations of French Agriculture, limited though they are at present, are leading the way for the emergence of a dual agriculture with, on one side, the maintenance of an agricultural sector still based on family farming and, on the other, the progressive constitution of farms of another type altogether, resulting from capital/labour separation and therefore based on salaried employment - or even piecework - as the dominant social relation. These are capitalist-type farms even if, at first, the capital remains in the hands of a collective made up of related members. They also raise new questions concerning their consequences for the remuneration of farm work and related employment, more broadly.

\section{Bibliography}

Albaladejo Ch., Arnauld de Sartre X. et Gasselin P., 2012 : Agriculture entrepreneuriale et destruction du travail dans la pampa argentine, Les Agricultures de firmes 1. Organisations et

\footnotetext{
16 In France, the significant weight of State subsidies in farmers' income, and the fact that these are - wrongly - included in the gross profit of the farm and therefore in the "value added" calculation, somewhat affects the readability of the impact of value added distribution modes on the farmers' income (Cochet, 2015).

17 A very real phenomenon in France where the lack of farm salaried work is on the increase, as shown by Catherine Laurent (communication, conference SFER 2015).
} 
financiarisation, Etudes rurales juillet-décembre 2012,190 : 177-192, Editions de l'Ecole des Hautes Etudes en Sciences Sociales, Paris.

Bélières J.F., Bonnal, Ph., Bosc, P-M, Losch B., Marzin J., Sourisseau J.M., 2013, Les agricultures familiales du monde. Définitions, contributions et politiques publiques, CIRADAFD, Montpellier (276 p.).

Buisson M., Bazin G., Desriers M., Penhouet R., Simon P. et Roux B., 2014. L'emploi agricole. Une situation préoccupante, difficile à inverser, doc de travail, déc. 2014.

Carlier D. et Perrier-Cornet Ph., 2007 : L'agriculture ultratechnologique, un avenir pour la ruralité ?, Séminaire Entrepreneurs Villes et Territoires, Les amis de l'Ecole de Paris, séance du 9 mai 2007.

CER-FRANCE, 2005 : Le concept d'exploitation agricole a-t-il un avenir, Les Cahiers CER FRANCE, février 2005.

CER-FRANCE, 2007 : «L'exploitation agricole flexible», Les Cahiers du CER FRANCE, mai 2007.

CER-FRANCE, 2009 : Veille Economique agriculture, La Lettre $\mathrm{N}^{\circ} 16$ - juin 2009.

CER-FRANCE, 2014 : Les voies juridiques vers l'entreprise agricole flexible, Les Cahiers CER FRANCE, février 2014.

Cochet H., 2008: Vers une nouvelle relation entre la terre, le capital et le travail en agriculture, Etudes foncières $n^{\circ} 134$ juillet-août 2008 : 24-29.

Cochet (H), 2015 : Comparative Agriculture, Quae/Springer, the Netherlands (154 p.).

Cochet H., 2015. Controverses sur l'efficacité économique des agricultures familiales : indicateurs pour une comparaison rigoureuse avec d'autres agricultures, Revue Tiers Monde, $N^{\circ} 221$ janvier-mars 2015, pp. 9-25, Armand Colin, Paris.

Cochet H., 2016: Séparation capital/travail, flexibilité et rémunération des facteurs de production: la fin de l'exploitation agricole familiale ? Economie Rurale $\mathrm{n}^{\circ} 357-358$ /janviermars 2017, 7-22.

Cochet H., Merlet M., 2011, "Land grabbing and share of the value added in agricultural processes. A new look at the distribution of land revenues", International Academic Conference 'Global Land Grabbing'6 - 8 April 2011, University of Sussex, Brighton, UK.

Cochet H., 2017: Capital-Labour Separation and Unequal Value Added Distribution: Repositioning Land Grabbing in the General Movement of Contemporary Agricultural Transformations, The Journal of Peasant Studies, 2017, Vol 44, $N^{\circ} 3$. http://dx.doi.org/10.1080/03066150.2017.1311866

Darpeix A., La main-d'oeuvre salariée en agriculture: histoire d'une invsibilité, Demeter 2013, pp. 269-296. 
Devienne S., 2014, Systèmes de production et politiques agricoles aux Etats-Unis, HDR Université de Paris X Nanterres.

Devienne S., Bazin G. et Charvet J.P., 2005 : Politique agricole et agriculture aux Etat-Unis : évolution et enjeux actuels, Ann. Géo., $n^{\circ}$ 641, 2005, p. 3-26.

Dufumier M., Bergeret P., 2002, «Analyser la diversité des exploitations agricoles », in Mémento de l'agronome, CIRAD - GRET, Ministère des Affaires étrangères, Paris, pp. 321344.

FAO, 2014: The State of Food and Agriculture, Innovation in Family Farming, Rome (139 p.)

FNSafer, 2014 : Le prix des terres 2013. Analyse des marchés fonciers ruraux, FNSafer, Paris.

Gault J., Marty S., Menard J-N. et Pringault J-M., 2013. Evaluation des mesures prises dans le cadre de la Loi d'orientation agricole de 2006 pour faciliter la transmission des exploitations agricoles et le financement des facteurs de production par des capitaux extérieurs, Tome 1 Rapport, CGAAER n ${ }^{\circ}$ 12064, MAAF.

Grosso, S., 2009, « Les pools de culture : diversité des combinaisons financières et productives », DÉMÉTER 2010, Club Déméter, Paris, Armand Colin : 223-254.

Guibert M. 2013. Les formes associatives de production agricole en argentine et en Uruguay: entre territoire et réseau ?, Etudes rurales 1/ 2013 (n¹91), p. 77-90.

Hervieux B., Purseigle F., 2009: «Pour une sociologie des mondes agricoles dans la globalisation », Etudes rurales, janvier-juin 2009, 183 : 177-200.

Institut de l'Elevage, 2013 : L'élevage d'herbivores au Recensement agricole 2010. Cheptels, Exploitations, Productions, Le Dossier Economie de l'Elevage $n^{\circ}$ 440-441 - novembredécembre 2013.

Laurent C., 2015, communication, colloque SFER 2015 (ref à compléter).

Ministère de l'Agriculture, de l'agroalimentaire et de la Forêt, Agreste: Recensement Agricole de 2000.

Ministère de l'Agriculture, de l'agroalimentaire et de la Forêt, Agreste: Recensement Agricole de 2010.

Nguyen G. et Purseigle F., 2012: Les exploitations agricoles à l'épreuve de la firme. L'exemple de la Camargue, Les Agricultures de firmes 1. Organisations et financiarisation, Etudes rurales juillet-décembre 2012,190 : 99-118, Editions de l'Ecole des Hautes Etudes en Sciences Sociales, Paris.

Olivier-Salagnac V. et Legagneux B., 2012. L'agriculture de firme : un fait émergent dans le contexte agricole français?, Les Agricultures de firmes 1. Organisations et financiarisation, Etudes rurales juillet-décembre 2012,190 : 77-98, Editions de l'Ecole des Hautes Etudes en Sciences Sociales, Paris. 
Pluvinage, J., 2011. Innovations, alternatives, et diversité des exploitations agricoles. Pour 212, 187-197.

Posada, Marcelo et Mariano Martínez de Ibarreta — 1998, « Capital financiero y producción agrícola : los pools de siembra en la región pampeana », Realidad económica 153 : 112-135.

Séronie J-M., 2014: L'agriculture française: une diva à réveiller ? QUAE éditions, Paris.

Société des Agriculteurs de France : La SEP Céres

www.agriculteursdefrance.com/Upload/Conferences/Fichier2_128.pdf:

Sourisseau J-M. (ed), 2014, Agricultures familiales et mondes à venir, QUAE éditions, Versailles (360 p.).

Tchayanov A., 1966. The Theorie of Peasant Economy, Homewood, Illinois, RD, Irwin (first edition in Dutch, 1923; first edition in Russian 1924). 